\title{
PENERAPAN MODEL PEMBELAJARAN KOOPERATIF PROBING- PROMPTING UNTUK MENINGKATKAN PRESTASI BELAJAR PESERTA DIDIK
}

\author{
Cici Maria Putri*, Elva Yasmi Amran, Erviyenni
}

Program Studi Pendidikan Kimia, Fakultas Keguruan dan Ilmu Pendidikan Universitas Riau, Kampus Binawidya KM 12,5, Pekanbaru 28293, Riau, Indonesia.

\begin{tabular}{l} 
Informasi Artikel \\
\hline Sejarah Artikel: \\
Diterima: 03-07-2019 \\
Disetujui : 22-07-2020 \\
Dipublikasikan: 24-07-2020 \\
\hline Keywords: \\
Probing-Prompting \\
learning, \\
Learning achievement, \\
Stoichiometry, \\
\hline
\end{tabular}

Telah dilaksanakan penelitian di SMAN 5 Pekanbaru yang bertujuan untuk meningkatkan prestasi belajar peserta didik padapokok bahasan stoikiometri di kelas X MIPA. Jenis penelitian ini adalah penelitian ekseperimen dengan Design Randomized Control Group Pretest-Posttest. Sampel dari penelitian adalah peserta didik kelas X MIPA 3 sebagai kelas eksperimen. Kelas eksperimen adalah kelas yang diterapkan model pembelajaran kooperatif tipe Probing-Prompting. Teknik analisis data digunakan adalah uji-t. Berdasarkan hasil uji analisis data diperoleh thitung >ttabel yaitu 3,59>1,67, dan besar pengaruh peningkatan prestasi belajar peserta didik sebesar 15,56\%.Dapat disimpulkan bahwa penerapan model pembelajaran kooperatif tipe probing-prompting dapat meningkatkan prestasi belajar peserta didik pada pokok bahasan stoikiometri di kelas X MIPA SMA Negeri 5 Pekanbaru dengan besar pengaruh peningkatan yaitu sebesar $15,56 \%$.

\begin{abstract}
A b s tract
The research has been conducted at SMAN 5 Pekanbaru which aims to improve student learning achievement on the subject of ion stoichiometry in class X MIPA. This type of research is an experimental study with adesign Randomized Control Group pretest-posttest.. The sample from the study was students of class X MIPA 3 as an experimental class. The experimental class is the class applied to the type Probing-Prompting type cooperative learning model. The data analysis technique used is the t-test. Based on the results of the data analysis test, tcount > ttable is 3,59> 1.67, with value of its influence to student learning achievement is $15,56 \%$. It can be concluded that the application of Probing-Prompting type cooperative learning model can improve student learning achievement on the subject of ion stoichiometry in class X MIPA of SMA Negeri 5 Pekanabru with value of its influence to student learning achievement is $15,56 \%$.
\end{abstract}

\footnotetext{
*Alamat korespondensi:

e-mail: cici.mariaputri97@gmail.com

No. Telf: +6281212712988
} 


\section{PENDAHULUAN}

Proses belajar mengajar merupakan suatu proses yang mengandung serangkaian perbuatan guru dan siswa, atas dasar hubungan timbal balik yang berlangsung dalam situasi edukatif untuk tujuan tertentu (Dimyati dan Mudjiono, 2013). Proses belajar mengajar lebih efektif apabila peserta didik dapat berpartisipasi dan berperan aktif di dalamnya. Proses belajar mengajar keberhasilan belajar peserta didik sangat diharapkan, salah satu keberhasilan yang ingin dicapai adalah peningkatan prestasi belajar yang diperoleh peserta didik tersebut. Untuk mewujudkan keberhasilan dalam belajar ini tidak terlepas dari peran guru. Dalam proses belajar mengajar, guru mempunyai tugas untuk mendorong, membimbing, dan memberi fasilitas belajar bagi peserta didik untuk mencapai tujuan (Slameto,2013). Proses belajar mengajar harus lebih mengacu kepada apa yang harus di pelajari dengan menggunakan model yang dapat mengaktifkan peserta didik dalam belajar. Model pembelajaran adalah suatu perencanaan atau suatu pola yang digunakan sebagai pedoman dalam melaksanakan proses pembelajaran (Trianto, 2012).

Sardiman (2009) menyatakan bahwa dalam belajar sangat diperlukan adanya aktivitas, tanpa aktivitas belajar itu tidak mungkin akan berlangsung dengan baik proses pembelajaran. Aktivitas dalam proses belajar mengajar merupakan rangkaian kegiatan yang meliputi keaktifan peserta didik dalam mengikuti pelajaran, bertanya hal yang belum jelas, mencatat, mendengar, berfikir, membaca, dan segala kegiatan yang dilakukan yang dapat menunjang prestasi belajar.

Hasil wawancara dengan salah seorang guru bidang studi kimia di SMA Negeri 5 Pekanbaru, dapat disimpulkan pada kelas X MIPA SMA Negeri 5 Pekanbaru pada tahun ajaran 2017/2018 peserta didik merasa kesulitan dalam memahami materi dan mengerjakan soal-soal pada pokok bahasan stoikiometri. Hal ini ditandai dengan $75 \%$ nilai ulangan harian peserta didik di bawah Kriteria Ketuntasan Minimum (KKM). KKM yang ditetapkan di SMA Negeri 5 Pekanbaru untuk mata pelajaran kimia adalah 75. Proses pembelajaran pada materi stoikiometri di sekolah sudah menggunakan metode diskusi, namun peserta didik yang bertanya dan menanggapi pertanyaan dari guru masih sedikit, akibatnya tidak semua peserta didik terlibat aktif selama proses pembelajaran. Guru juga memberikan latihan yang dikerjakan secara individu maupun kelompok, namun yang aktif mengerjakannya hanya peserta didik yang pintar saja, sedangkan peserta didik lainnya masih mengalami kesulitan dalam mengerjakan soal-soal yang diberikan oleh guru, sehingga membuat peserta didik menyalin tugas yang dibuat oleh temannya. Peserta didik yang tidak terlibat aktif dalam proses pembelajaran dan tidak mengerjakan tugas yang diberikan guru secara mandiri, mengakibatkan peserta didik tidak menguasai materi sehingga prestasi belajar peserta didik tidak memuaskan.

Kurangnya keaktifan peserta didik menyebabkan hasil belajar menjadi rendah karena keaktifan dalam proses pembelajaran merupakan salah satu faktor yang mempengaruhi prestasi belajar. Untuk mendapatkan prestasi belajar yang baik dan memuaskan, guru sebagai fasilitator harus menggunakan model tertentu agar peserta didik dapat terlibat aktif dalam proses pembelajaran.

Salah satu alternatif model pembelajaran yang diharapkan dapat meningkatkan keaktifan peserta didik ialah model pembelajaran Kooperatif Tipe Probing-Prompting. Model pembelajaran Probing-Prompting merupakan model pembelajaran dimana guru menyajikan berbagai pertanyaan yang menuntun dan menggali pengetahuan peserta didik. Menurut Siswanto (2016) kelebihan dari model pembelajaran Probing-Prompting ialah: mendorong siswa berfikir aktif, mengembangkan keberanian dan keterampilan siswa dalam menjawab dan mengemukakan pendapat melalui langkahlangkah pembelajarannya.

Penelitian penerapan model Probing-Prompting telah dilakukan oleh Susanti, (2017) telah menerapkan pembelajaran model probing-pomting untuk meningkatkan kemapuan berfikir kritis 
siswa. Penelitian ini dijalankan pada subjek matematika di kelas XI IPA MAN Kota Bengkulu dan diperoleh hasil penelitian terdapat peningkatan kemampuan berpikir kritis siswa selama menerapkan pembelajaran berbasis model pobing-pomting. Penelitian yang dilakukan oleh Diasputri, et al., (2012) yaitu pengaruh model pembelajaran Probing-Prompting berbantu lembar kerja berstruktur terhadap hasil belajar peserta didik materi hidrokarbon dengan persentase ketuntasan belajar mencapai 91,18\%. Diartini dan Ratnawuri (2017) juga telah melakukan penelitian tentang Penggunaan model cooperative learning tipe Probing-Promting berbantu media Flash Card terhadap hasil belajar IPS terpadu menunjukkan nilai thitung $=3,85>$ tabel $=1,72$. Ulya dan Kartono (2012) telah mengembangkan keefektifan penerapam pembelajaran model kooparatif tipe probing-promting dengan penilaian produk, hasil penilitian ini menemukan prestasi kelas eksperimen bereda secara siginifikan dibandingkan dengan kelas control.

Penelitian ini bertujuan untuk menerapkan model pembelajaran kooperatif probing-prompting untuk meningkatkan prestasi belajar peserta didik. Penelitian ini dijalankan pada Sekolah Menengah Atas Negeri 5 Pekanbaru di Kelas X MIPA.

\section{METODE PENELITIAN}

Penelitian dilaksanakan dilaksanakan di kelas X MIPA SMA Negeri 5 Pekanbaru Tahun ajaran 2018/2019. Waktu pengambilan data dilakukan dari bulan Maret-April 2019. Populasi dalam penelitian adalah seluruh peserta didik kelas X MIPA SMA Negeri 5 Pekanbaru yang terdiri dari 4 kelas yaitu X MIPA 1, X MIPA 2, X MIPA 3, dan X MIPA 4. Sampel diambil berdasarkan hasil analisis uji normalitas dan uji homogenitas nilai ulangan materi redoks. Dari uji normalitas dan uji homogenitas diketahui bahwa kelas X MIPA 2 dan X MIPA 3 berdistribusi normal dan mempunyai kemampuan yang sama (homogen), maka kedua kelas tersebut dijadikan sebagai sampel. Diperoleh Kelas X MIPA 3 sebagai kelas eksperimen dan kelas X MIPA 2 sebagai kelas kontrol. Bentuk penelitian adalah penelitian eksperimen dilakukan terhadap dua kelas dengan Desain Randomized Control Group Pretest-Posttest seperti Tabel 1.

Tabel 1. Rancangan Penelitian (Nazir, 2014)

\begin{tabular}{cccc}
\hline Kelas & Pretest & Perlakuan & Posttest \\
\hline Eksperimen & $\mathrm{T}_{0}$ & $\mathrm{X}_{1}$ & $\mathrm{~T}_{1}$ \\
Kontrol & $\mathrm{T}_{0}$ & - & $\mathrm{T}_{1}$ \\
\hline
\end{tabular}

Teknik pengumpulan data dalam penelitian adalah teknik test. Data yang dikumpulkan diperoleh dari: (1). Data hasil nilai test soal ulangan materi redoks sebagai data awal yang digunakan untuk uji homogenitas. (2). Nilai pretest dan posttest pada kelas eksperimen dan kelas kontrol (pokok bahasan stoikiometri) yang digunakan untuk uji hipotesis. Sedangkan teknik analisis data yang digunakan pada penelitian adalah uji-t. pengujian statistik dengan uji-t dapat dilakukan berdasarkan kriteria data yang berdistribusi normal. Oleh sebab itu, sebelum dilakukan pengolahan data, terlebih dahulu dilakukan uji normalitas menggunakan uji Liliefors. Jika harga Lmaks $<$ Ltabel, maka data berdistribusi normal. Harga Ltabel diperoleh dengan Persamaan (1) (Rostiana, 2014).

$$
L=\frac{0,886}{\sqrt{\mathrm{n}}}
$$

Setelah data berdistribusi normal, kemudian dilakukan uji homogenitas dengan menguji varians kedua sampel (homogen atau tidak) terlebih dahulu dengan Persamaan 2:

$$
F=\frac{\text { Varians Terbesar }}{\text { Varians Terkecil }}
$$


Kemudian dilanjutkan dengan uji kesamaan rata-rata menggunakan uji-t dua pihak untuk mengetahui kehomogenan kemampuan kedua sampel. Rumus uji-t pada uji homogenitas juga digunakan untuk melihat perubahan hasil belajar berupa prestasi belajar peserta didik antara kelas eksperimen dan kelas kontrol. Uji hipotesis yang digunakan merupakan uji-t pihak kanan dengan rumusan Persamaan 3.

$$
\frac{x_{1}-x_{2}}{S g \sqrt{\frac{1}{n^{1}}}+\frac{1}{n_{\jmath}}}
$$

Dengan Sg merupakan standar deviasi gabungan yang dapat dihitung menggunakan Persamaan 4 (Sudjana, 2015).

$$
\mathrm{Sg}=\frac{\left(n_{1}-1\right) S_{1}^{2}+\left(n_{2}-1\right) S_{2}^{2}}{n_{1}+n_{2}-2}
$$

Untuk menunjukkan besarnya pengaruh penerapan model pembelajaran Kooperatif Tipe Probing-Promptingterhadap peningkatan prestasi belajar peserta didik dilakukan dengan menentukan koefisien penentu (determinasi) dengan Persamaan 5.

$$
\mathrm{Kp}=\mathrm{r} 2 \times 100 \%
$$

Dimana, nilai ditentukan dengan Persamaan 6 dan nilai t ditentukan dengan Persamaan 7 (Riduwan, 2009).

$$
\begin{aligned}
& \mathrm{r} 2=\frac{t^{2}}{t^{2+n-2}} \\
& \mathrm{t}=\frac{\mathrm{r} \sqrt{\mathrm{n}-2}}{\sqrt{1-\mathrm{r}^{2}}} \mathrm{r}^{2}=\frac{\mathrm{t}^{2}}{\mathrm{t}^{2}+\mathrm{n}-2}
\end{aligned}
$$

\section{HASIL DAN PEMBAHASAN}

\subsection{Uji Homogenitas}

Sebelum dilakukan uji homogenitas terlebih dahulu dilakukan uji normalitas soal ulangan materi redoks karena data yang digunakan untuk uji homogenitas dalam penelitian adalah data yang diperoleh dari nilai soal ulangan materi redoks yang telah terdistribusi normal. Hasil analisis uji normalitas dapat dilihat pada Tabel 2 .

Tabel 2. Hasil uji normalitas

\begin{tabular}{ccccccc}
\hline Kelas & $\mathbf{N}$ & $\overline{\mathrm{X}}$ & $\mathbf{S}$ & Lmaks & Ltabel & Keterangan \\
\hline X MIPA 1 & 33 & 70,21 & 20,75 & 0,19 & 0,15 & Tidak berdistribusi \\
X MIPA 2 & 36 & 72,25 & 19,35 & 0,13 & 0,15 & Berdistribusi normal \\
X MIPA 3 & 36 & 72,50 & 20,26 & 0,09 & 0,15 & $\begin{array}{c}\text { Berdistribusi normal } \\
\text { Tidak berdistribusi } \\
\text { X MIPA 4 }\end{array}$ \\
\hline
\end{tabular}


Berdasarkan Tabel 2 dapat dilihat bahwa dari empat kelas, didapat 2 kelas berdistribusi normal yaitu kelas X MIPA 2, X MIPA 3 dimana harga $\mathrm{L}_{\text {maks }}<\mathrm{L}_{\text {tabel. }}$ Selanjutnya data diuji variansnya kemudian diuji kesamaan rata-rata dua pihak untuk mengetahui kehomogenan kedua kelas. Uji varians dilakukan sebagai syarat dari uji homogenitas, karena data yang diuji harus mempunyai varians yang sama. Hasil pengolahan data uji homogenitas dapat dilihat pada Tabel 3.

Tabel 3. Hasil pengolahan data uji homogenitas

\begin{tabular}{ccccccccc}
\hline Kelas & $\mathbf{N}$ & $\sum \mathbf{X}$ & $\overline{\mathrm{X}}$ & $\mathbf{F}$ hitung & $\mathbf{F}$ tabel & thitung & ttabel & Keterangan \\
\hline XMIPA 2 & 36 & 2601 & 72,25 & & & & & \\
X MIPA 3 & 36 & 2610 & 72,50 & 1,05 & 1,72 & $-0,05$ & 2,00 & Homogen \\
\hline
\end{tabular}

Berdasarkan Tabel 3 menunjukkan hasil analisis uji homogenitas nilai ulangan materi redoks dari dua kelas yaitu kelas X MIPA 2 dan X MIPA 3 yang memiliki Fhitung $<$ Ftabel yaitu $1,05<1,72$. Hal ini menunjukkan bahwa kedua kelompok sampel homogen. Kelas yang homogen ini menyatakan bahwa kelas tersebut layak untuk dilakukan penelitian dengan memilih secara acak (di undi) untuk dijadikan kelas eksperimen dan kontrol dan diperoleh kelas X MIPA 3 sebagai kelas eksperimen dan kelas X MIPA 2 sebagai kelas kontrol.

\subsection{Uji Hipotesis}

Data yang digunakan untuk uji hipotesis dalam penelitian adalah selisih antara nilai pretest dan posttest yang menunjukkan besarnya peningkatan prestasi peserta didik sebelum dan sesudah mempelajari materi stoikiometri dengan dan tanpa menggunakan model pembelajaran kooperatif tipe Probing-Prompting. Hasil pengolahan data uji hipotesis dapat dilihat pada Tabel 4.

Tabel 4. Hasil uji hipotesis

\begin{tabular}{ccccccccc}
\hline Kelas & $\mathbf{N}$ & $\sum \mathbf{X}$ & $\overline{\mathrm{X}}$ & $\sum \mathbf{X}_{\mathbf{2}}$ & $\mathbf{S}_{\text {gab }}$ & thitung & ttabel & keterangan \\
\hline Eksperimen & 36 & 1626 & 45,17 & 78132 & \multirow{2}{*}{12,81} & 3,59 & 1,67 & $\begin{array}{c}\text { Hipotesis } \\
\text { diterima }\end{array}$ \\
Kontrol & 36 & 1236 & 34,33 & 49232 & & & &
\end{tabular}

Uji hipotesis yang didapat dari selisisih nilai pretest-postest dilakukan dengan menggunakan uji t pihak kanan, hasil uji hipotesis thitung $=3,59$ dan nilai tabel pada $\alpha=0,05$ dengan $\mathrm{dk}=70$ adalah 1,67 artinya thitung lebih besar daripada tabel yaitu 3,59>1,67 sehingga hipotesis diterima, bahwa model pembelajaran kooperatif tipe Probing-Prompting dapat meningkatkan prestasi belajar peserta didik pada pokok bahasan Stoikiometri di kelas X MIPA SMA Negeri 5 Pekanbaru.

\subsection{Peningkatan Hasil Belajar Peserta Didik}

Data yang digunakan untuk melihat pengaruh model pembelajaran terhadap hasil belajar peserta didik adalah data hasil perhitungan uji hipotesis dengan $t=3,59$ dan $n=70$. Hasil perhitungan untuk $\mathrm{r}_{2}$ adalah 0,1556 dengan besar koefisien pengaruh 15,56\%. Hal ini menunjukan bahwa penerapan model pembelajaran Kooperatif Tipe Probing-Prompting memberikan konstribusi terhadap peningkatan prestasi belajar peserta didik pada pokok bahasan stoikiometri di kelas X MIPA SMAN 5 Pekanbaru sebesar $15,56 \%$.

\section{PEMBAHASAN}

Penelitian dilakukan di kelas X MIPA SMAN 5 Pekanbaru untuk melihat peningkatan prestasi belajar peserta didik pada pokok bahasan stoikiometri dengan menerapkan model pembelajaran 
kooperatif tipe Probing-Prompting. Didapatkan bahwa penerapan model pembelajaran model pembelajaran kooperatif tipe Probing-Prompting dapat meningkatkan prestasi belajar peserta didik pada pokok bahasan sttoikiometri dengan besar pengaruh peningkatan prestasi belajar peserta didik pada pokok bahasan stoikiometri dengan menentukan koefisien penentu (Kp) yaitu sebesar 15,56\% .

Penerapan model pembelajaran kooperatif tipe Probing-Prompting dapat membuat peserta didik lebih aktif dalam proses kegiatan belajar mengajar secara individu dan seluruh peserta didik terlibat dalam proses pembelajaran. Cara peneliti untuk meningkatkan keaktifan ialah dengan memberi pertanyaan dan memilih peserta didik secara acak, selanjutnya peserta didik tersebut diberikan serangkaian pertanyaan. Probing question adalah "pertanyaan yang bersifat menggali untuk mendapatkan jawaban yang lebih lanjut dari peserta didik yang bermaksud mengembangkan kualitas jawaban, sehingga jawaban berikutnya lebih jelas, akurat serat lebih beralasan" sedangkan Prompting question, pertanyaan ini bermaksudkan untuk " menuntun peserta didik agar ia dapat menemukan jawaban yang lebih benar".

Dalam proses pembelajaran penerapan model Probing-Prompting terlihat peserta didik berfikir secara aktif, pemahaman konsep yang semakin membaik, peserta didik lebih berani dalam menjawab dan menngemukakan pendapat serta dengan pertanyaan tersebut dapat memusatkan perhatian peserta didik ketika sedang mengantuk ataupun sedang ribut. Hal ini sesuai dengan Shoimin (2014) bahwa kelebihan dari model pembelajaran Probing-Prompting ialah: a) mendorong siswa aktif berfikir, (b) memberikan kesempatan kepada peserta didik untuk menyatakan hal - hal yang kurang jelas sehingga guru dapat menjelaskan kembali, (c) perbedaan pendapat antar peserta didik dapat dikompromikan atau diarahkan, (d) pertanyaan dapat menarik dan memusatkan perhatian peserta didik, (e) mengembangkan keberanian dan keterampilan peserta didik dalam menjawab dan mengemukakan pendapat.

Meningkatnya keaktifan peserta didik menyebabkan hasil belajar menjadi tinggi, karena keaktifan dalam proses pembelajaran merupakan salah satu faktor yang mempengaruhi prestasi belajar. Untuk mendapatkan prestasi belajar yang baik dan memuaskan, guru sebagai fasilitator harus menggunakan model tertentu agar peserta didik dapat terlibat aktif dalam proses pembelajaran. Model pembelajaran Probing-Prompting dalam penerapannya peserta didik dihadapkan pada situasi baru, misalnya dengan memperhatikan gambar, rumus atau situasi lainnya yang mengandung permasalahan yang berkaitan dengan materi stoikiometri. Contoh situasi baru pada pertemuan pertama ialah menayangkan slide yang mengandung permasalahan "Bila dalam kehidupan sehari-hari kita mengenal satuan jumlah berupa lusin, maka 1 lusin itu jumlahnya(12) 1 rim kertas itu jumlahnya (500 Lembar) lalu apakah satuan untuk jumlah partikel materi? Apakah lambang dari satuan tersebut?" Setelah itu peneliti mengajukan pertanyaan kepada peserta didik yang sesuai dengan tujuan pembelajaran atau indikator kepada seluruh peserta didik. Contoh pertanyaan pada pertemuan pertama adalah " apakah yang dimaksud dengan 1 mol zat? Berapakah jumlah partikel molekulnya?" Peserta didik diberikan waktu berdiskusi secara berkelompok untuk merumuskan jawaban dari pertanyaan yang telah diberikan. Dengan bekerja sama akan mendorong peserta didik untuk dapat saling bertukar informasi, meningkatkan keakraban kerja sama karena pembelajaran dilakukan dengan sistem kerja kelompok. Pertanyaan tersebut di perkuat oleh Slameto (2013) bahwa bekerja di dalam kelompok akan meningkatkan cara berfikir peserta didik sehingga dapat memecahkan masalah dengan lebih baik dan lancar.

Guru menunjuk salah satu peserta didik secara acak untuk menjawab pertanyaan. Jika jawabannya relevan dan benar maka guru meminta tanggapan kepada peserta didik lain tentang jawaban tersebut untuk meyakinkan bahwa seluruh peserta didik terlibat dalam kegiatan yang sedang berlangsung. Jika peserta didik tersebut mengalami kemacetan jawaban dalam hal ini jawaban yang diberikan kurang tepat, tidak tepat atau diam, maka guru mengajukan pertanyaan-pertanyaan lain yang jawabannya merupakan petunjuk jalan penyelesaian jawaban dari pertanyaan sebelumnya. Lalu dilanjutkan dengan pertanyaan menuntun peserta didik berfikir pada tingkat yang lebih tinggi, sampai 
dapat menjawab sesuai dengan kompetensi dasar atau indikator. Pertanyaan yang dilakukan pada langkah ini diajukan pada beberapa peserta didik yang berbeda agar seluruh peserta didik terlibat dalam seluruh kegiatan Probing-Prompting. Dan yang terakhir guru mengajukan pertanyaan akhir pada peserta didik yang berbeda untuk lebih menekankan bahwa tujuan pembelajaran/indikator tersebut benar-benar telah dipahami oleh seluruh peserta didik.

Pengaruh model pembelajaran kooperatif tipe Probing-Prompting pada pokok bahasan stoikiometri dalam 4 kali pertemuan diterapkan dalam proses pembelajran terjadi peningkatan keaktifan dalam proses pembelajaran, yaitu partisipasi peserta didik untuk menjawab pertanyaan dari guru serta menanggapi jawaban dari peserta didik lainnya mengalami peningkatan untuk setiap pertemuannya, serta kualitas jawaban yang semakin membaik, baik dari aspek kesesuaian jawaban dengan topik pembahasan, kecepatan waktu dan percaya diri peserta didik yang semakin meningkat. Hal ini menunjukkan bahwa aktivitas pembelajaran Probing-Prompting dapat meningkatkan keaktifan peserta didik, menumbuhkan kepercayaan diri serta melatih peserta didik mengkomunikasikan ideidenya sehingga peserta didik dapat lebih mudah memahami materi stoikiometri dengan baik.

Pengaruh penerapan model pembelajaran kooperatif tipe Probing-Promptinng juga dapat dilihat dari rata-rata nilai LKPD dan rata-rata nilai evaluasi kelas eksperimen dan kelas kontrol. Dalam 4 kali pertemuan menerapkan model pembelajaran kooperatif tipe Probing-Prompting didapat nilai rata-rata LKPD dan nilai rata-rata evaluasi peserta didik kelas eksperimen lebih tinggi dibandingkan dengan kelas kontrol, hal ini disebabkan karena peserta didik lebih aktif dalam proses pembelajaran, dapat menemukan konsep dan terlibat langsung dalam kegiatan pembelajaran.

Peningkatan hasil belajar peserta didik dapat juga dilihat dari penilaian sikap dan penilaian keterampilan yang berlangsung selama proses pembelajaran. Penilaian sikap dan penilaian keterampilan peserta didik kelas eksperimen dan kelas kontrol pada masing-masing aspek mengalami peningkatan karena peserta didik telah memiliki motivasi dalam diri untuk mengikuti pembelajaran dengan penerapan model pembelajaran kooperatif tipe Probing-Prompting.

\section{KESIMPULAN DAN REKOMENDASI}

\subsection{Kesimpulan}

Berdasarkan hasil penelitian dan pembahasan dapat disimpulkan bahwa: Penerapan model pembelajaran kooperatif tipe Probing-Prompting dapat meningkatkan prestasi belajar peserta didik pada pokok bahasan Stoikiometri di kelas X MIPA SMA Negeri 5 Pekanbaru. Besarnya pengaruh penerapan model pembelajaran kooperatif tipe Probing-Prompting terhadap peningkatan prestasi belajar peserta didik pada pokok bahasan stokiometri di kelas X MIPA SMA Negeri 5 Pekanbaru adalah sebesar $15,56 \%$.

\subsection{Rekomendasi}

Berdasarkan kesimpulan yang diperoleh, peneliti merekomendasikan Model pembelajaran kooperatif tipe Probing-Prompting dapat dijadikan sebagai salah satu alternatif model pembelajaran kimia khususnya pada pokok bahasan stoikiometri yang dapat meningkatkan prestasi belajar peserta didik.

\section{DAFTAR PUSTAKA}

Diartini, R., Ratnawuri, T. 2017. Penggunaan model cooperative learning tipe probing prompting berbantu media flash card terhadap hasil belajarips terpadu. Jurnal Promosi; Jurnal Pendidikan Ekonomi UM Metro. 5(1): 57-63 
Diasputri, A., Nurhayati, S., Sugiyo, W. 2013. Pengaruh model pembelajaran probing-prompting berbantuan lembar kerja berstruktur terhadap hasil belajar. Jurnal Inovasi Pendidikan Kimia. 79(1); 1103-1111

Dimyati dan Mudjiono. 2013. Belajar dan Pembelajaran. Rineka Cipta. Jakarta.

Nazir. M. 2014. Metode Penelitian. Ghalia Indonesia. Bogor.

Riduwan. 2009. Dasar-Dasar Statistika. Alfabeta. Bandung.

Sardiman. 2009. Interaksi dan Motivasi Belajar Mengajar. PT Raja Grafindo Persada. Jakarta.

Shoimin, A. 2014. Model Pembelajaran Inovatif dalam Kurikulum 2013. Ar-Ruzz. Yogyakarta.

Siswanto W., Ariani, D. 2016. Model Pembelajaran Menulis Cerita Buku Panduan Untuk Guru Ketika Mengajar Menulis Cerita. PT. Refika Aditama. Bandung.

Slameto. 2013. Belajar dan Faktor-faktor yang Mempengaruhinya. Rineka Cipta. Jakarta.

Sudjana. 2015. Metode Statistik. Tarsito. Bandung.

Sundayana, R. 2014. Statistika Penelitian Pendidikan. Alfabeta. Bandung.

Susanti, E. 2017. Penerapan model pembelajaran probing-prompting untuk meningkatkan kemampuan berpikir kritis matematis siswa kelas xi.ipa man 1 kota bengkulu. Jurnal Pendidikan Matematika Raflesia. 2(1): 96-107

Trianto. 2012. Model-Model Pembelajaran Inovatif Berorientasi Konstruktivitik, Prestasi Pustaka. Jakarta.

Ulya, H. Masrukan, Kartono. 2012. Keefektifan penerapan model pembelajaran kooperatif tipe probing-prompting dengan penilaian produk. Unnes Journal of Mathematics Education. 1(1); 26-31 